\title{
Poučavanje materinskoga jezika u razrednoj nastavi
}

Marinko Lazzarich. 2017. Metodika Hrvatskoga jezika u razrednoj nastavi. Rijeka: Sveučilište u Rijeci, Učiteljski fakultet. 352 str. ISBN 9789537917111

DOI: 10.21066/carcl.libri.2018-07(01).0010

Znanstvena monografija Metodika Hrvatskoga jezika u razrednoj nastavi autora Marinka Lazzaricha namijenjena je sustavu visokoškolskoga obrazovanja u području nastavničkih studija, studentima, učiteljima, pripravnicima i odgojiteljima. Osim što upućuje na temeljne postavke metodike materinskoga jezika i književnosti, sadržaj djela, utemeljen na dugogodišnjoj nastavnoj, stručnoj i znanstvenoj praksi autora, usmjeren je na osvještavanje učitelja i odgojitelja o važnosti pristupa pouci materinskoga jezika u nižim razredima osnovne škole.

Uz predgovor i uvod, djelo je sadržajno strukturirano u devet poglavlja kojima se donose teorijska polazišta i povezuju teorijske tvrdnje s praktičnim primjerima, upoznajući čitatelja s ključnim sastavnicama nastave Hrvatskoga jezika: nastave početnoga čitanja i pisanja, nastave jezika, jezičnoga izražavanja i stvaranja, nastave književnosti, medijske kulture i lektire u razrednoj nastavi. Dodatno se naglašava važnost povezivanja nastavnih sadržaja unutarpredmetnom i međupredmetnom korelacijom. Zasebno poglavlje donosi pregled povijesti metodike hrvatskoga jezika. Pored navedenih ključnih poglavlja, djelo sadrži više sasvim učinkovito smislenih i homogenih potpoglavlja u kojima se razmatraju važni aspekti didaktičko-metodičkih postavki nastave u odgojno-obrazovnome procesu s naglaskom na poučavanju i učenju sadržaja predmeta Hrvatski jezik.

Usmjeravajući se na učeničke kompetencije prema Nacionalnom okvirnom kurikulumu u poglavlju „Hrvatski jezik kao nastavni predmet“, važnost se pridaje razvoju kompetencije komunikacije na materinskome jeziku koja se odnosi na osposobljenost za pravilno stvaralačko, usmeno i pisano izražavanje te jezično djelovanje u različitim društvenim i kulturnim situacijama. Hrvatski jezik u razrednoj nastavi obuhvaća književnost i jezik, uključujući i područje pravopisa, usmenoga i pisanoga izražavanja i medijske kulture. Donosi se kratki prikaz razvoja nastavnih programa Hrvatskoga jezika u 20. stoljeću te razmatra materinski jezik u okružju novih medija.

U potpoglavlju „Metodika hrvatskoga jezika“ pristupa se razmatranju Metodike s teorijskoga i empirijskoga proučavanja, oblikovanja i razvijanja strukturno cjelovitoga obrazovnoga procesa nastavnoga predmeta Hrvatski jezik, uvažavajući različite načine s obzirom na slojevitost i višedimenzionalnost nastavnoga predmeta. Upravo se u potpoglavlju „Predmetni kurikul“ iznosi pojmovno određenje kurikula suvremene škole kao i skrivenoga kurikula u svojstvu odgojno-obrazovnoga tijeka te njegova oblikovanja koje se temelji na znanstvenim spoznajama o učenju i poučavanju i jasno definiranim ishodima učenja kojima učenici trebaju ovladati.

Sadržaj poglavlja „Nastava početnoga čitanja i pisanja“ sveobuhvatno utemeljuje učenje početnoga čitanja i pisanja putem razlikovanja dvaju osnovnih pristupa: funkcionalnoga i komplementarnoga. Donosi se pojašnjenje odrednica: kulture čitanja, prepoznavanja glasova u riječi, nastave početnoga pisanja, slovopisa i pravila početnoga pisanja, pisanih vježbi u prvome razredu, diktata, prepisivanja te se analizira nastavna jedinica u početnome čitanju i pisanju. Potpoglavljem „Slikovnica u nastavi početnoga čitanja i pisanja“ prikazuju se različite funkcije slikovnice u nastavi: informacijsko- 
odgojna, spoznajna, iskustvena, estetska i zabavna te se navodi kako u osmišljavanju načina primjene slikovnice u nastavnoj praksi postoje različiti oblici i metode rada, čime se uklanja metodička jednoličnost, nastavna stereotipija te osjećaj prisile u kojem je učenik sveden na razinu pasivnoga slušatelja. U poučavanju Hrvatskoga jezika, prikazom metodičkoga modela interpretacije slikovnice, pridaje se važnost slikovnici kojom se, osim u nastavi početnoga čitanja i pisanja te lektire, može koristiti i u nastavnim područjima književnosti, jezika, jezičnoga izražavanja i medijske kulture.

Kako osposobljavanje učenika za jezičnu komunikaciju nije moguće bez usvajanja pravopisne norme standardnoga jezika, u poglavlju „Nastava jezika“ upoznaje se čitatelja s osnovnim pravopisnim i pravogovornim pravilima, osnovama morfologije i sintakse. Iznose se jezični sadržaji u razrednoj nastavi, prikazuje se struktura nastavnoga sata jezika uz praktične primjere nastavnih sati.

U poglavlju „Nastava književnosti“ ističe se osnovna zadaća nastavnoga područja književnosti, spoznavanje i doživljavanje, tj. recepcija književnoga teksta. Književni tekst u razrednoj nastavi ima i važnu odgojnu funkciju. Iznose se obrazovni sadržaji po razredima s naglaskom na upoznavanju književnih vrsta, prikazuje nastavni sat književnosti, iznosi interpretacija lirske pjesme te se pridaje važnost drami i lutki u nastavi književnosti. Lektira je u razrednoj nastavi opisana kao sastavni dio nastave književnosti putem koje učenici stječu svjesnost čitanja, susreću se s najboljim ostvarenjima nacionalne književnosti i djelima svjetskih klasika. Problematizirana je sintagma „obvezna lektira“ koja u učenikovoj svijesti izaziva negativne konotacije kao i problem (ne)čitanja školske populacije. Prikazani su primjeri praktičnih vježbi i zanimljivi kreativni postupci u nastavi lektire primjerima i opisanim strategijama koje se mogu primjenjivati u neposrednome radu s učenicima. Naglašava se važnost doživljajne nastave književnosti.

Osim razvijanja sposobnosti jezičnih djelatnosti, u nastavnome području ,Jezično izražavanje i stvaranje“ najveća se pozornost pridaje stvaralačkomu izražavanju učenika na hrvatskome standardnome jeziku i zavičajnome idiomu. Sadržajima potpoglavlja detaljnije se analiziraju slušanje, govorenje, čitanje i pisanje. Opisuje se interpretativno čitanje, čitanje naglas, pripovijedanje, pričanje s naglaskom na vježbama izgovora i vrjednotama govornoga jezika. Važnost se pridaje i pisanju iznošenjem programskih odrednica pisanja po razredima s naglaskom na učeničkom sastavku kao vezanomu tekstu i završnomu rezultatu procesa pisanja. Dio teksta posvećen je nastavnoj jedinici jezičnoga izražavanja. Potpoglavljem „Načelo zavičajnosti“ naglašava se da kreativna uporaba zavičajnoga idioma u nastavnoj praksi pridonosi razvoju jezično-komunikacijskih sposobnosti koje mogu rezultirati boljim ovladavanjem standardnoga jezika. Upućuje se na mogućnosti dijalekta u nastavi jezika, osvrće na odnos drugih zemalja prema dijalektu te se iznose istraživački dosezi.

Osnovne funkcije medija u pružanju mogućnosti stvaralačke primjene u nastavi Hrvatskoga jezika iznose se u poglavlju „Nastava medijske kulture“. Prikazuje se uvođenje učenika u obrazovne sadržaje u nastavi medijske kulture upoznavanjem s dječjim filmovima, televizijskim emisijama i lutkarskim predstavama. Potpoglavljem je detaljnije opisan film i filmsko stvaralaštvo te prikazan metodički model interpretacije filma. U potpoglavlju „Obrazovni potencijal stripa“ na zanimljiv se način prikazuje strip kao popularni medij koji u literarnoj komunikaciji može smanjiti nesrazmjer između školskoga programa i životne stvarnosti. Iznosi se primjer interpretacije stripa o Ivani Brlić-Mažuranić. 
U poglavlju „Povezivanje nastavnih sadržaja“ opisuje se korelacija u nastavi koja podrazumijeva povezivanje odgojno-obrazovnoga procesa u skladnu cjelinu. Iznose se primjeri povezivanja sadržaja unutar istoga obrazovnoga područja (unutarpredmetna korelacija) i spajanja različitih predmetnih područja (međupredmetna korelacija), uz prikaz primjera integriranoga dana.

Navodeći kako ,[s]voj današnji status ova disciplina može zahvaliti predanom radu brojnih hrvatskih metodičara” (226), autor uvodi čitatelja u poglavlje „Pregled povijesti metodike hrvatskoga jezika“. Osvrt obuhvaća činjenični prikaz hrvatskoga školstva u 19. stoljeću s naznakom djelovanja i doprinosa uglednih metodičara hrvatskoga jezika i književnost do šezdesetih godina 20. stoljeća i nakon šezdesetih godina 20. stoljeća. U potpoglavljima je pomoću metodičkih krugova prikazan sveučilišni regionalizam suvremene hrvatske metodike te metodički prinosi znanstvenika i stručnjaka iz srodnih odgojno-obrazovnih područja.

Temeljem sadržajnoga razmatranja i uvida u opsežan broj referiranih bibliografskih podataka, izvora i literature može se zaključiti da je djelo sveobuhvatno, utemeljeno na stručnim i znanstvenim načelima te da prikazuje najvažnije sadržaje metodike hrvatskoga jezika. Budući da je predmetno područje Hrvatskoga jezika složeno, a i sama znanost o poučavanju predmeta slojevita, u knjizi se očituje interdisciplinarnost znanstvene dimenzije i pojmovnoga razmatranja. Izabrani predlošci, rezultati istraživanja navođenih autora i posebice prikazani metodički modeli razrade nastavnih sati pružaju dobru osnovicu za uspostavljanje unutarpredmetnih i međupredmetnih suodnosa nastavnih sadržaja. Knjiga uključuje primjere koji pokazuju funkcionalnost teorijskih polazišta u praksi i koji će zasigurno pomoći čitateljima u primjerenoj recepciji i primjeni njezinih postavki u nastavi.

Petra Pejić Papak

\section{Oblici konceptualne proze: poetike hipertekstualnosti}

\section{Andrijana Kos-Lajtman. 2016. Poetika oblika: suvremene konceptualne i hiper- tekstualne proze. Zagreb: Naklada Ljevak. 288 str. ISBN 978-953-303-920-6}

DOI: 10.21066/carcl.libri.2018-07(01).0011

Poetika oblika primjeren je naslov knjige koju je napisala Andrijana Kos-Lajtman. Riječ je o jednoj u nas podosta neuobičajenoj znanstvenoj temi: eksperimentalnoj i konceptualnoj prozi. Neuobičajenoj zbog teme, ne toliko zbog analiziranih romana u studiji, koliko zbog intencije da radikalnim književnim oblicima da primjereno mjesto u panteonu hrvatske proze. Knjiga je zanimljiva i zbog još nečega. Naime, u posljednje vrijeme svjedoci smo kako se na primjerima u suštini tradicionalnih pripovjednih modela primjenjuje teorijska ,teška artiljerija“. Kos-Lajtman radi obratno - prozu koju uzima za pomno čitanje, kompleksnu i složenu, recepcijski zahtjevnu, analizira s nevjerojatnom dozom svakojake mjere. Analitički, pregledno i razumno. Razumno, jer ne inzistira na razmetljivome pokazivanju teorijske kompetencije, nego svoj povijesni, komparatistički i teorijski inventar prilagođava interpretacijskomu horizontu, odnosno književnosti samoj.

Autorica svako poglavlje uzorno strukturira, neovisno o tome je li riječ o dječjoj književnosti, teorijskim problemima ili romanima Jasne Horvat. Prvo u fokus stavlja 